\title{
Sanctions Against Non-State Actors
}

\author{
Nigel D. White*
}

\section{Introduction}

The aims of this chapter are: first to contextualise the imposition of sanctions against non-state actors (NSAs) - to explain the trend towards them and their goals and purposes. It considers the notion of NSAs (terrorists, rebels ...) drawing a line between them and state actors, which is not as straightforward as might first appear (shown, for example, by the case of individual politicians or governmental employees). The next step is to undertake a legal doctrinal analysis of such measures, first in terms of their legal nature (whether they are imposed to punish illegal acts or to tackle threats to the peace), and the values they are meant to protect (security, human rights, democracy ...). The chapter then considers their legal bases (in treaties, collective countermeasures, custom ...). The legal obligations imposed by them are analysed (whether they bind members, all states, NSAs themselves), and their legal effects considered (whether they criminalise, punish directly or indirectly, override existing obligations). Any legal limitations upon them are identified (from general principles of international law such as non-intervention to specific legal regimes such as international human rights law). The chapter also considers issues of implementation, oversight and enforcement of sanctions against NSAs; and accountability for misapplied or overly injurious sanctions. The legal analysis is based on relevant constitutional, international and regional laws, as well as the practice of the UN, the EU, and the US, ${ }^{1}$ as leading actors in the imposition of this type of measure. The aim is to consider the above issues in the light of the particular purposes, form and effects of sanctions against NSAs. Several studies of paradigmatic sanctions regimes against NSAs conclude the chapter, and conclusions are drawn particularly on the development of a more sophisticated legal framework to govern sanctions taken against NSAs.

\section{The Trend Towards Sanctions against NSAs}

\footnotetext{
* Professor of Public International Law, University of Nottingham, UK. My thanks to Kerry Senior for her invaluable research assistance on this chapter.

${ }^{1}$ For more detail on EU sanctions see Chapter 4 of this volume by Marco Gestri.
} 
The post-Cold War period has seen a sharp move towards 'smart' sanctions against individuals or entities deemed responsible for breaches of international law or threats to international peace and security. This comports with a move in international law to supplement, but not replace, state responsibility with individual responsibility for breaches of international law. The main motivation has been to ensure that innocent citizens and civilians are not punished for the wrongdoings of their leaders. This is part of the move towards protecting human security alongside, but not instead of, state security and generally towards the protection of civilians. ${ }^{2}$ This trend was identified by the UN's High Level Panel in its 2004 report 'A More Secure World':

As a result of growing concern over the humanitarian impact of comprehensive sanctions, the Security Council stopped imposing them after the cases of Iraq, former Yugoslavia and Haiti, and turned exclusively to the use of financial, diplomatic, arms, aviation, travel and commodity sanctions, targeting the belligerents and policy makers most directly responsible for reprehensible policies. ${ }^{3}$

While these new-style targeted sanctions have raised their own human rights concerns in terms of due process, rights to property, privacy and freedom of movement, they are quantitatively less than the human rights impact of punitive sanctions imposed against a state and, therefore, against the population of a state, as shown by the massive suffering caused to the people of Iraq by the collective comprehensive sanctions imposed from $1991-2003 ;{ }^{4}$ and that caused to the people of Cuba by unilateral sanctions imposed by the US against Cuba from 1960 onwards. ${ }^{5}$ To quote again from the High Level Panel Report of 2004:

Targeted sanctions (financial, travel, aviation or arms embargoes) are useful for putting pressure on leaders and elites with minimal humanitarian consequences, provide a less costly alternative to other options and can be tailored to specific circumstances. By isolating violators of international standards and laws, even modest sanctions measures (including sports embargoes) can serve an important symbolic purpose. The threat of sanctions can be a powerful means of deterrence and prevention. ${ }^{6}$

The High Level Panel made it clear that the move to smart sanctions had to be combined with better monitoring, implementation and enforcement to make them more effective. ${ }^{7}$ There can be little doubt that smart sanctions imposed against the regimes of Saddam Hussein or Fidel Castro would have been better for the populations of Iraq and Cuba but the question remains as to whether such measures imposed against members of a regime or government are going to affect sufficient change in behaviour as to be an adequate replacements or alternatives to general sanctions.

The move towards smart or targeted sanctions is, perhaps too readily, explained as a development of more precise, more surgical measures against states, or more accurately state leaders but also against 'elites' within states. In a sense, such measures may be best considered as measures against state actors; given that the leaders of states are paradigmatic state agents. ${ }^{8}$ So it may be argued that they are beyond the scope of this chapter, but this really depends upon the scope of the measures: whether they are confined to paradigmatic state agents or whether they extend more broadly to cover influential and powerful persons within a state's elite. In this instance, sanctions are a mixture of measures against

\footnotetext{
${ }^{2}$ See UN Doc A/RES/66/290 (2012), containing the United Nations' current understanding of human security.

${ }^{3}$ Report of the Secretary-General's High-level Panel on Threats, Challenges and Change, 'A more secure world: our shared responsibility' (UN, 2004) para 80.

${ }^{4}$ J. Gordon, Invisible War: The United States and the Iraq Sanctions (Harvard University Press 2010) 86-102.

${ }^{5}$ N.D. White, The Cuban Embargo Under International Law: El Bloqueo (Routledge 2015) 99-124.

${ }^{6}$ High Level Panel (2004), above n.3, para 179.

${ }^{7}$ Ibid., para 180. See also Report of the Informal Working Group of the Security Council on General Issues of Sanctions (UN Doc S/2006/997).

${ }^{8}$ Their acts being those of the state under Articles 4 and 5, Articles on the Responsibility of States for Internationally Wrongful Acts 2001.
} 
state actors and NSA's. This type of 'mixed' regime was initially applied to Libya in 2011, when the resolutions contained non-forcible measures against a range of individuals from the regime and from Gaddafi's family. ${ }^{9}$ Those measures were imposed in part to fulfil the Security Council's primary responsibility for peace and security but also, in part, as a response to crimes against humanity that appeared to have been committed in Libya, necessitating a referral to the International Criminal Court. ${ }^{10}$ As the post-Gaddafi era in Libya descended into violence and chaos, the Security Council again found itself imposing measures against NSAs in Libya (including Al-Qaida and Islamic State) on the basis of a threat to the peace, but also targeting individuals planning or committing violations of international human rights and humanitarian law. ${ }^{11}$

The confusion over whether the term NSAs covers regime elites is largely due to the lack of legal definition of NSA which is, in itself, something of an 'empty term', comprising as it does 'actors which apparently only have in common that they are not the state, and not governmental'. ${ }^{12}$ Whether spouses of Presidents or Prime Ministers of countries are state or non-state actors is a question that would potentially fill a whole chapter, but the telling question is whether it makes any real difference to whether sanctions may be lawfully imposed on them as well as the legal parameters governing the application of such measures. As has been stated, once international law was supplemented with notions of individual responsibility as well as state responsibility for breaches of international law, there may seem to be no reason to doubt the legality of such measures. However, whereas the vast majority of breaches of international law can give rise to state responsibility there are only specific regimes, such as international criminal law and aspects of others such as international humanitarian law, the violation of which can give rise to individual responsibility. This signifies that if sanctions are imposed on individuals for a violation of international law it can only be for breach of those norms or because the violative conduct of the individual is imputable to the state. It would also have to be established that states or organisations imposing such measures have the right or duty to do so under international law. However, if sanctions are imposed in order to tackle threats to international peace presented by the activities of individuals, or groups of individuals, then there is no need to establish norm violation; the key question is then whether the state or organization imposing sanctions in such circumstances has the right or power to do so.

With exceptions such as Haiti in the 1990s, ${ }^{13}$ and Libya in 2011, the UN has often failed to adopt smart sanctions against state leaders (witnessed by the inconclusive debates on Zimbabwe and Syria) ${ }^{14}$ although historically it has engaged in limited sanctions against states in the form of arms embargoes, starting with that imposed against South Africa in $1977 . .^{15}$ The UN has concentrated its targeted sanctions against non-state actors such as members of terrorist and rebel groups. Indeed, it

\footnotetext{
${ }^{9}$ UN Doc S/RES/1970 (2011) op paras 15-17, explicitly invoked Article 41 of the UN Charter and imposed a travel on listed individuals (members of the regime, and Gaddafi's family), an assets freeze on individuals under a separate list (a shorter list of members of Gaddafi's family).

${ }^{10}$ Ibid, op para 4.

${ }^{11}$ UN Doc S/RES/2213 (2015) op para 11(a).

12 A. Peters, L. Koechlin, G.F. Zinkernagel, 'Non-State Actors as Standard Setters: Framing an Issue in an Interdisciplinary Fashion' in A. Peters, L. Koechlin, T. Forster, G.F. Zinkernagerl (eds), Non-State Actors as Standard Setters (Cambridge University Press 2009) 14.

${ }^{13}$ UN Doc S/RES/841 (1993). Note, however, that these were imposed against the de facto authorities in Haiti i.e. a military regime that had overthrown the democratically elected (under UN supervision) government of Jean-Bertrand Aristide - J.M. Farrall, United Nations Sanctions and the Rule of Law (Cambridge University Press 2007) 326. See also targeted sanctions imposed against the military junta that had seized power from the democratically elected authorities of Haiti in 1997 - UN Doc S/RES 1132 (1997).

14 In July 2008, Russia and China vetoed a draft resolution (UN Doc S/2008/447) that would have imposed and arms embargo and targeted sanctions (travel ban and assets freeze) against President Mugabe and 13 top military and government officials in Zimbabwe following a flawed and violent elections process (UN Doc S/PV 5933, 11 July 2008). In October 2011 Russia and China vetoed a draft resolution (UN Doc S/2011/612) that threatened measures under Article 41 against members of the Syrian regime (UN S/PV 6627, 4 October 2011). ${ }^{15}$ UN Doc S/RES/418 (1977).
} 
has been argued that for the UN the concept of NSAs is confined to such groups. ${ }^{16}$ Thus, the story of the development of smart sanctions is not simply one of a response to humanitarian concerns arising from general sanctions against states, since the UN had established practice of imposing such sanctions against NSAs, for example, with such measures taken against UNITA in 1993, before full evidence of the damage caused by comprehensive sanctions against Iraq was known.

Subject to the point made above (re smart sanctions taken against 'elites' and the difficulty of delineating state from non-state in that 'elite') it is important to keep in mind the distinction between smart sanctions against state actors and those taken against NSAs as they arise from different political contexts. Smart sanctions against leaders of states are successors to those imposed generally against states; they are taken within the modern inter-state paradigm, while sanctions against NSAs are part of the post-Cold War move towards enforcing individual responsibility in a broad sense within a postmodern paradigm where sovereignty is variable and international relations are not solely structured around the state. However, although in part a development of the idea of individual responsibility, it will be shown that UN sanctions imposed against NSAs primarily aim to tackle threats to peace and security posed by these actors, and not to punish those actors for breaches of international law for which they might be individually responsible, and in that way they share characteristics with sanctions imposed against states. Sanctions imposed by the US and the EU are more mixed in terms of what they are aimed at - NSA behaviour that is a threat to peace and security or behaviour that is a breach of international norms.

The realisation that NSAs could represent a real (existential) threat to established state actors, culminating in states and state-based organizations taking coercive measures against them, was something of a slow process. In fact, the early post-Cold War instances of sanctions against NSAs were imposed against those holding power but who had not attained full status as state actors; measures in the 1990s were imposed against de facto governments (e.g. Taliban) or rebel groups with de facto belligerent status (e.g. UNITA) ${ }^{17}$ Even historically the first UN sanctions regime was imposed against the illegitimate white racist regime in S. Rhodesia in the late 1960s, a de facto government, though the measures imposed were not targeted and had a wider impact on the population. ${ }^{18}$ This shows that the first 'generation' of smart sanctions against NSAs were pragmatically driven measures against those in control of territories even though they had not achieved recognition as legitimate leaders of states. A clear departure in the UN from measures analogous to sanctions against states was only taken with the extension of the Taliban sanctions regime imposed in 1999 to Al-Qaida in 2000 and, in so doing, removing the link between Al Qaida and the territory of Afghanistan, ${ }^{19}$ which in 2011 was followed by the complete separation of the two regimes (discussed below).

A contrast can be made with measures taken by the EU which, because of the narrower state consensus necessary to take decisions to impose sanctions and broader agreement on the values to be protected or promoted, shows a faster and deeper trend towards sanctions directed against regime elites (for example, in Zimbabwe and Russia), ${ }^{20}$ although lesser development has occurred as regards NSAs such as terrorist groups. ${ }^{21}$ Targeted EU sanctions were initially imposed in 2002 by the Council

\footnotetext{
${ }^{16}$ P. Alston, 'The "Not-a-Cat" Syndrome: Can the International Human Rights Regime Accommodate NonState Actors?' in P. Alston (ed), Non-State Actors and Human Rights (Oxford University Press 2005) 17.

${ }^{17}$ Both discussed later in the chapter.

${ }^{18}$ UN Doc S/RES 232 (1966).

${ }^{19}$ Farrall, supra n.13, at 131.

${ }^{20}$ See, for example, EU targeted sanctions against regime individuals in Zimbabwe (Council Decision 2011/101/CFSP, OJ L 42, 16 February 2011, p.6) and Syria (Council Decision 2013/255/CFSP OJ L 147, 1 June 2013, p.14). Targeted sanctions were imposed against certain Russian individuals responsible for actions which undermined or threatened the territorial integrity, sovereignty and independence of Ukraine following intervention in Ukraine (Council Decision 2014/145/CFSP, OJ L 78, 17 March 2014, p. 16).

${ }^{21}$ Measures against Al Qaida in Common Position 2002/402/CFSP, OJ L 139, 29 May 2002, p.4; measures against individuals and entities associated with Al Qaida in Council Regulation (EC) No 881/2000, OJ L 139, 29 May 2002, p.9. See also Common Position 2001/931/CFSP OJ L 344, 28 December 2001, p.93; Council
} 
against individuals in Zimbabwe on the basis of its assessment that the 'Government of Zimbabwe continues to engage in serious violations of human rights and of the freedom of opinion, of association and of peaceful assembly'. It decided that 'for as long as the violations occur the Council deems it necessary to introduce restrictive measures against the Government of Zimbabwe and those who bear a wide responsibility for such violations'. ${ }^{22}$

The EU's measures are clearly framed as a response to a violation of international human rights standards occurring in Zimbabwe. In contrast, in the case of measures imposed by the US in relation to Zimbabwe, the initial Executive Order of the President in 2003 'determined that the actions and policies of certain members of the Government of Zimbabwe and other persons to undermine Zimbabwe's democratic processes or institutions contributing to the deliberate breakdown in the rule of law in Zimbabwe, to politically motivated violence and intimidation in that country, and to political and economic instability in the southern African region, constitute an unusual and extraordinary threat to the foreign policy of the United States', and declared 'a national emergency to deal with that threat'. ${ }^{23}$ The formula of an executive Presidential Order finding of a threat to the foreign policy and national security of the United States and declaring a national emergency to deal with the threat has been used on a number of occasions by the US to tackle a variety of perceived threats by imposing targeted sanctions against individuals and other NSAs, ${ }^{24}$ although other more normative based determinations such as violations of human rights have been used by Congress to pass legislation imposing targeted sanctions as well. ${ }^{25}$ The Presidential executive power to impose sanctions, derived from the International Emergency Economic Powers Act (IEEPA) originally adopted in 1977, ${ }^{26}$ has been criticised on the grounds that 'experience with IEEPA raises concerns that it may be used casually for spurious national emergencies'. ${ }^{27}$

\section{The Nature and Purposes of Sanctions Against NSAs}

Regulation (EC) No 2580/2001, OJ L 344, 28 December 2001, freezing funds and economic resources of certain persons, groups and entities with a view to combating terrorism.

${ }^{22}$ Restrictive measures against Zimbabwe in Common Position 2002/145/CFSP, OJ L 50/1, 21 February 2002.

${ }^{23}$ Executive Order 13288-Blocking Property of Persons Undermining Democratic Processes or Institutions in Zimbabwe, 68 FR 11457 March 10, 2003.

${ }^{24}$ See for example: Executive Order 13611-Blocking Property of Persons Threatening the Peace, Security, or Stability of Yemen 77 FR May 16, 2012; Executive Order 13338-Blocking Property of Certain Persons and Prohibiting the Export of Certain Goods to Syria, 69 FR 26751 May 13, 2004; Executive Order 13067Blocking Sudanese Government Property and Prohibiting Transactions With Sudan, 62 FR 59989, November 5, 1997; Executive Order 13664-Blocking Property of Certain Persons with Respect to South Sudan FR April 3 , 2014; Executive Order 13536 - Blocking Property of Certain Persons Contributing to the Conflict in Somalia April 13, 2010; Executive Order 13660-Blocking Property of Certain Persons Contributing to the Situation in Ukraine, 79 FR 13493, March 10 2014; Executive Order 13466 - Continuing Certain Restrictions With Respect to North Korea and North Korean Nationals 73 FR 36787 June 27, 2008; Executive Order 13566-Blocking Property and Prohibiting Certain Transactions Related to Libya, 76 FR 11315 February 25, 2011; Executive Order 13441-Blocking Property Of Persons Undermining The Sovereignty Of Lebanon Or Its Democratic Processes And Institutions 72 FR 43499 August 3, 2007; Executive Order 12722 - Blocking Iraqi Government Property And Prohibiting Transactions With Iraq, 55 FR 31803 August 3, 1990; Executive Order 13413Blocking Property of Certain Persons Contributing to the Conflict in the Democratic Republic of the Congo 71 FR 64105, October 31, 2006; Executive Order 13396-Blocking of Property of Certain Persons Contributing to the conflict in Côte d'Ivoire 71 FR 7389, February 10, 2006; Executive Order 13310_Blocking Property of the Government of Burma and Prohibiting Certain Transactions 68 FR 44853, July 30, 2003; Executive Order 13405-Blocking Property of Certain Persons Undermining Democratic Processes or Institutions in Belarus 71 FR 35485, June 20, 2006; Executive Order 13219-Blocking Property of Persons Who Threaten International Stabilization Efforts in the Western Balkans, 68 FR 34777, June 29, 2001.

${ }^{25}$ For example: S.2142 - Venezuela Defense of Human Rights and Civil Society Act of 2014, $113^{\text {th }}$ Congress, (2013-2014). See also notes 57-58 below.

${ }^{26} 50$ U.S.C. 1701-2 (1982).

${ }^{27}$ B.E. Carter, 'International Economic Sanctions: Improving the Haphazard U.S. Legal Regime' (1987) 75 California Law Review 1159 at 1238. 
The legal nature of sanctions under international law, whether imposed against state actors or NSAs, has not been fully agreed upon ${ }^{28}$ and so it is important to try shed light on this while considering the nature and purpose of sanctions specifically taken against NSAs. The problem for international lawyers is that while analogies with domestic legal orders can often be misleading, in general terms, sanctions are central to any legal system, whether national or international. Kelsen takes this truism and applies it to the international legal order, arguing that sanctions are an inherent component of any legal order including one providing for collective security. Kelsen wrote that 'a social order guaranteeing collective security is by its very nature a legal order, and a legal order is a system of norms providing for sanctions' ${ }^{29}$ Sanctions, for Kelsen, are 'coercive reactions against an actual violation of the law', or alternatively, against suspected or expected violations. ${ }^{30}$ This formulation does allow for some anticipatory sanctions but the trigger remains an actual or potential violation of the law. However, it is clear that in the international order, especially in its collective security component, 'sanctions' are not confined to actual or potential violations of international law, rather the primary triggers are actual or threatened ruptures of the peace. Kelsen accepts that legal systems generally recognise the legitimacy of coercive measures that have no relation to actual or potential violations of the law but remain necessary to maintain or restore peace and security. However, the examples given by Kelsen show that this is the exception rather than the rule within national legal orders; his examples include the forcible destruction of buildings to prevent the spread of fire, or the forcible internment of people suffering infectious diseases in order to prevent an epidemic from spreading. ${ }^{31}$ Arguably in the international order these sorts of exceptions are the norm, so that sanctions are imposed to address threats to the peace, whether or not those threats entails actual or possible violations of the law. ${ }^{32}$ However, the trend towards sanctions against NSAs might be indicative of a move towards punishment for violations of the law being the primary aim, given that this development has occurred against the background of a move towards addressing individual responsibility for core crimes. The examples given in this chapter include a consideration of whether there has been a move towards sanctions being imposed for breaches of international law.

Given that the overriding purpose of targeted sanctions against NSAs, whether to punish or prevent, is to change the behaviour of individuals either directly (to stop them for example from committing terrorist acts) or indirectly (to influence states or NSAs to stop them supporting the acts or threats that are of concern), it is important to discern whether it is behaviour that constitutes a threat or the behaviour that constitutes the crime that it the target. The intended deterrent aspect of sanctions as punishment is to prevent future breaches, whereas the deterrent effects of sanctions to tackle threats to the peace is the immediate end of the behaviour that comprises the threat. Of course the dichotomy of threat and crime is not always easy to maintain and criminal behaviour, particularly at the international level, can be a (part of) a wider threat to international peace. ${ }^{33}$ When imposing targeted

\footnotetext{
${ }^{28}$ F. Dopagne, 'Sanctions and Countermeasures by International Organizations' in R. Collins and N.D. White (eds), International Organizations and the Idea of Autonomy: Institutional Independence in the International Legal Order (Routledge 2011) 180.

${ }^{29}$ H. Kelsen, Collective Security under International Law (Naval War College 1957) 101. For alternative positivist views of sanctions see H.L.A. Hart, The Concept of Law (Clarendon 1961) 91-5; J.L. Brierly, 'Sanctions' (1932) 17 Transactions of the Grotius Society 68.

${ }^{30}$ Kelsen, above n.29 at 102.

${ }^{31}$ Ibid.

32 J.L. Kunz, 'Sanctions in International Law' (1960) 52 AJIL 324 at 329. But see V. Gowlland-Debbas (ed), United Nations Sanctions and International Law (Kluwer, 2001) 7-9.

${ }^{33}$ See for example UN Doc S/RES/1857 (2008) op para 4, which, inter alia, imposed measures against: political and military leaders of foreign armed groups operating in the Democratic Republic of the Congo who impede the disarmament and the voluntary repatriation or resettlement of combatants belonging to those groups; as well as political and military leaders operating in the Democratic Republic of the Congo and recruiting or using children in armed conflicts in violation of applicable international law; and individuals operating in the Democratic Republic of the Congo and committing serious violations of international law involving the targeting of children or women in situations of armed conflict, including killing and maiming, sexual violence, abduction and forced displacement.
} 
measures against NSAs in the Central African Republic, the UN Security Council, acting under a general determination that the violence there constituted a threat to regional peace and stability, imposed measures against individuals who were involved in planning, directing, or committing acts that violate international human rights law or international humanitarian law; ${ }^{34}$ as well as against individuals "engaging in or providing support for acts that undermine the peace, stability or security of the CAR, including acts that threaten or violate transitional agreements, or that threaten or impede the political transition process, including a transition toward free and fair democratic elections, or that fuel violence'. 35

Nonetheless, there is stark difference between the nature and purpose of sanctions imposed against NSAs (for example members of a rebel group) aimed at bringing them to the negotiating table, and sanctions imposed on them as punishment for crimes they might have committed during their insurgency. Furthermore, analysis might reveal that it is better to separate out different forms of nonforcible measures and confine 'sanctions' to a narrow response to breaches of international law. Arguably such sanctions are more clearly grounded within the legal order than sanctions imposed to tackle an emergency situation arising from threats to peace and security. In this regard it may be argued that there are the equivalent of 'non-derogable' rights and duties, to borrow an analogy with human rights law, ${ }^{36}$ in the context of collective security responses to threats, but the legal framework is arguably pared down in international emergencies especially when the UN Security Council is acting under Chapter VII of the UN Charter.

This is not an argument for saying that there is no international legal order, but it is suggesting that the order is weak and so there is greater discretion within it to deal with what might be called the prelegal conditio sine qua non - that there is sufficient peace and security to preserve, or upon which to build, a legal order; what Hart might call the minimum content of natural law - self-evident conditions and norms of public order. ${ }^{37}$ Just as an infectious disease might temporarily justify that exercise of discretionary executive power at the national level, at the international level the equivalent of infectious diseases or rampant fires in the form of threats to international peace caused by civil wars, refugee flows, natural disasters, famine, climate change, arms proliferation, and yes infectious diseases, none of which are breaches of international law per se, are unfortunately too prevalent to be dealt with as the exception within the international legal order.

\section{The Legal Basis of Sanctions Against NSAs}

Further arguments for developing a more sophisticated legal typology of sanctions can be made when considering the variety of legal bases for sanctions against NSAs, ranging from measures taken under the framework of collective (international and regional) security law, to measures taken as a form of collective or unilateral countermeasures by states against influential actors within states, to forms of collective, multilateral and unilateral (criminal) punishment. The lack of clarity as to the legal basis and nature of targeted sanctions is encapsulated in the dispute about whether such measures, when imposed by the UN Security Council, are administrative or preventive measures, or forms of criminal punishment. $^{38}$

\footnotetext{
${ }^{34}$ UN Doc S/RES/2134 (2014) op para 37(b).

${ }^{35}$ UN Doc S/RES/2196 (2015) op para 11.

${ }^{36}$ See Article 4 International Covenant on Civil and Political Rights 1966.

${ }^{37}$ Hart, above n.29 at 188. N. Tsagourias and N.D. White, Collective Security: Theory, Law and Practice (Cambridge University Press 2013) 221.

${ }^{38}$ See for example Nabil Sayadi and Patricia Vinck v. Belgium, Communication No. 1472/2006, 29 December 2008, 16 IHHR 427 where the Human Rights Committee was of the view that such measures were administrative in nature and therefore did not attract due process guarantees; while the European Court of Justice in Joined Cases C-402/05 P and c-415/05, P Yassin Abdullah Kadi and Al Barakaat International Foundation $v$ Council of the European Union and Commission of the European Communities [2008] ECR I6351, found that they did violate such rights.
} 
A preliminary consideration of sanctions against NSAs would suggest that UN measures, at least, are certainly focused on the threat to the peace represented by the purposes, actions and activities of the targeted NSAs, rather than the punishment of individuals for actual or potential breaches of international law; while EU and other regional sanctions regimes tend to promote wider values other than peace and security, such as democracy and human rights..$^{39}$ US sanctions, as stated above, are often premised on threats to national security, although they are directed at responding to breaches of international law such as human rights law and to upholding wider values such as democracy and the rule of law. Unilateral sanctions by powerful states are imposed for a variety of reasons and under a range of legal justifications, from promoting human rights and democracy, to punishing individuals for international crimes and acts of terrorism. Unilateral sanctions, for example by the US against Cuba, are at least in part responses to breaches of international law; in that case the initial expropriations of UN properties and assets by Cuba following the revolution of 1959, the interventions by Cuba in Latin America and Africa in the 1960s and 1970s, with a focus from the 1980s on the denial of democracy and civil/political rights in Cuba; but they are also clearly ideologically motivated and a product of domestic US politics and law. ${ }^{40}$ Such on-going measures raise issues of the legality of the sanctions per se: as countermeasures, more broadly as forms of economic coercion, but they clearly violate general principles of international law of non-intervention and self-determination, and also more specific norms such as and socio-economic rights. ${ }^{41}$ These are not temporary measures aimed at ending a violation of international law by Cuba, and restoring normal relations between the two states, but are aimed at the form of government in Cuba and at changing that regime. ${ }^{42}$ The question is whether unilateral sanctions targeted at NSAs suffer from the same legal problems, or whether they are a 'smarter' form of measure designed to deter or punish those within states, and whether, as such, they operate within the confines of international law. The endemic problem even with this more precise form of sanctions is that, if they are punishment for violations of international law, they do not necessarily follow from any judicial determination of guilt, thereby rendering it automatically a violation of due process rights. This in part might explain why the US sanctions against NSAs are normally taken somewhat disingenuously under executive order as an emergency response to perceived threats to national security, which US Courts (in line with many national courts) are generally unwilling to challenge. ${ }^{43}$

Nonetheless, there does seem to be a gulf between the legal nature of collective sanctions designed to tackle threats, and unilateral sanctions designed to punish governments, regime elites and NSAs. As lawyers we may want to separate them for analysis, in particular by not viewing collective measures aimed at threats as 'sanctions' but as 'coercive non-forcible measures' $;{ }^{44}$ leaving us free to review the legality of each: collective and coercive non-forcible measures designed to restore public order, and unilateral punitive measures that are measures of self-help taken in response to alleged breaches of

\footnotetext{
${ }^{39}$ See, for example, Article 2(b) of the Charter of the Organizations of American States 1948 (as amended); Article 3(g)(h) Constitutive Act of the African Union 2000; Article 3.5 Treaty on European Union 2012 (consolidated version). For the relationship between regional organizations to the UN legal order, especially Article 53, which provides that regional enforcement action must be taken under the authority of the UNSC see N.D. White, 'The EU as a Regional Security Actor within the International Legal Order' in M. Trybus and N.D. White (eds), European Security Law (Oxford University Press 2007) 329, where law and practice are analysed to show that non-forcible measures are not fully within the restrictions imposed by Article 53.

${ }^{40}$ P.J Haney and W. Vanderbush, The Cuban Embargo: The Domestic Politics of an American Foreign Policy University of Pittsburgh Press 2005) 1-10.

${ }^{41}$ White, above n.5 at 139-44.

${ }^{42}$ On the limitations of countermeasures see Articles 49-54 Articles on State Responsibility 2001, above n.7.

${ }^{43}$ Carter, above n.27 at 1238 .

${ }^{44}$ Although the UNSC sometimes uses the term 'sanctions' for its non-forcible measures imposed under Chapter VII. See, for example, UN Doc S/RES/1333 (2000) op para 25, in which the UNSC 'Expresses its readiness to consider the imposition of further measures, in accordance with its responsibility under the Charter of the United Nations, with the aim of achieving full implementation of this resolution and resolution 1267 (1999), inter alia, taking into account the impact assessment referred to in paragraph 15 (d) with a view to enhancing the effectiveness of sanctions and avoiding humanitarian consequences'.
} 
international law. The question then is whether the doctrine of countermeasures is sufficient to contain and regulate sanctions; ${ }^{45}$ whereas when we are considering coercive non-forcible measures designed to tackle threats the legal parameters are potentially much broader, although it is contended they cannot disregard basic obligations of international law including those of human rights, especially ones of due diligence, applicable to the UN as an international legal person and as such subject to duties under customary international law. ${ }^{46}$ As obligations of conduct not result, ${ }^{47}$ due diligence obligations would require the UN to take measures to prevent, as far as possible, its actions having consequences for the human rights of the civilian population. For instance, during UN sanctions against the Haitian junta in the 1990s, there was strong evidence that the regime elite benefited from the black market that sprang up to compensate for the restrictions caused by sanctions, thereby pushing the general population further into poverty. ${ }^{48}$ It is questionable whether the humanitarian exception, standard in UN sanctions regimes, is enough to consider that the UN has fulfilled its due diligence obligations in these cases. ${ }^{49}$

Further analysis of practice reveals the legal effect of sanctions against NSAs, showing that they generally are applicable to (member) states when imposed by the UN or regional organization, binding them under the provisions of the constitutive treaty. ${ }^{50} \mathrm{UN}$ sanctions do not have direct effect within states, it is for states to implement them within their legal orders, for example, by making it illegal to trade with the targeted NSAs or requiring banks to freeze their assets, and the same is the case for regional organizations (with the EU's legal order being exceptional in this regard). The difficulty is that these obligations are not directed at the NSA, their immediate impact is on states and then in turn upon other actors such as banks, companies and individuals, by requiring them to act in certain ways towards the NSAs in order to restrict and isolate them so that their behaviour is curtailed. The focus on the state in terms of compliance with sanctions regimes is a natural result of the ongoing restrictive form of international legal order based on states that has not fundamentally changed even with the advent of powerful NSAs. Just as it is very difficult to make international law directly applicable to multinational businesses, ${ }^{51}$ we encounter the same problem with rebel groups, insurgents, organized criminals, terrorists etc.

Just as we might quibble with the term 'sanctions', we also might object to the rest of the title to this chapter 'against NSAs', because what we are really talking about, in the main, are coercive nonforcible measures placing duties upon states to take measures against NSAs, most commonly indirectly (by obliging legal persons within their domestic legal, such as banks and other financial institutions, to undertake certain measures, such as the freezing of funds and assets, against the NSAs under penalty for non-compliance). One interesting aspect to unravel here is the role of domestic criminal law as a weapon potentially used by states to fulfil their obligations to the UN, imposed by binding decisions on matters of peace and security, although normally the UN Security Council only calls upon states to bring proceedings and impose penalties against violators. ${ }^{52}$ The legitimacy of

\footnotetext{
45 J. Crawford, 'The Relationship between Sanctions and Countermeasures' in V. Gowlland-Debbas (ed), United Nations Sanctions and International Law (Kluwer 2001) 57.

46 The idea of duties of due diligence applying to the UN is only just gaining traction within the UN, although this does not mean that the UN is not so bound. See, for example, H.P. Aust, 'The UN Human Rights Due Diligence Policy: An Effective Mechanisms against Complicity of Peacekeeping Forces?' (2015) 20 Journal of Conflict and Security Law 61.

${ }^{47}$ S. Marks and F. Azizi, 'Responsibility for Violations of Human Rights Obligations', in J. Crawford, A. Pellet and S. Olleson (eds) The Law of International Responsibility (Oxford University Press, 2010)728-9.

${ }^{48}$ S. Chesterman, T.M Franck and D.M. Malone, Law and Practice of the United Nations: Documents and Commentary (Oxford: Oxford University Press, 2008) 359-60.

${ }^{49}$ But see Farrall, above n.13 at 224-7, who argues that proportionality is the applicable standard.

${ }^{50}$ For example, Article 25 UN Charter 1945; Article 215 Treaty on the Functioning of the European Union (as consolidated) 2012.

${ }^{51}$ See, example, the UN's Guiding Principles on Business and Human Rights 2011 (HR/PUB/11/04).

${ }^{52}$ For example, UN Doc S/RES/1267 (1999) op para 8, the UN Security Council 'calls upon States to bring proceedings against persons and entities within their jurisdiction that violate the measures imposed by paragraph 4 above and to impose appropriate penalties'.
} 
criminal sanctions being derived from measures aimed at tackling threats to the peace is enhanced if we see such measures as a response to breaches of public order norms rather than the exercise of purely discretionary power by the UN Security Council which, in turn, requires us to conceptualise 'peace' and 'security' as part of the international legal order. The Security Council has directly required states to criminalise the behaviour of NSAs or their supporters within their domestic legal orders, but this was in the form of a piece of 'legislation' in Resolution 1373 of 2001, aimed at tackling the general threat posed by international terrorism rather than one imposing 'sanctions' against specific threats. ${ }^{53}$

Certainly for those sanctions imposed against NSAs for the purpose of dealing with existential threats to states and their citizens, there are strong arguments that they should, at least temporarily, have priority over other obligations that states might have. Just as it might be necessary to temporarily suspend some human rights in times of genuine emergency when the life of the nation is threatened, and only for so long as it is under threat, so will it be necessary to suspend competing duties and rights when trying to tackle threats to international peace and security. The debates about Article 103 of the Charter veers between two polar interpretations of its provisions, so as to either assert supremacy over any competing or conflicting obligations including fundamental rights, or to deny its primacy altogether; ${ }^{54}$ while the approach of the European Court of Human Rights suggests a more practical approach - that the UN Security Council may be able to override clearly conflicting duties and rights in certain circumstances if it is explicit about what it is doing and presumably why it is doing it. ${ }^{55}$ The fact that to date it has not done so indicates that the Security Council is not confident in fulfilling its role as an international executive tasked with protecting international public order norms. UN Security Council practice in invoking the language of Article 103 is also equivocal as the case studies reveal. ${ }^{56}$

It must be noted too that there have been attempts by the US to assert supremacy of its unilateral sanctions in a different way, for instance those imposed against Cuba, namely by preventing other states and their nationals, as well as US companies and nationals, from trading with Cuba. ${ }^{57}$ Some US measures taken against Iran also purport to apply to foreign companies and nationals although, as with Cuba, these measures are only enforceable against foreign companies and nationals before US courts. ${ }^{58}$ These actions by the US can perhaps be seen as indicative that it has pretensions towards seeing itself, due to its power and its ideological history of exceptionalism, ${ }^{59}$ as some form of international executive with power over wider issues of peace and security, but it is questionable whether this is an accurate characterization, certainly in the case of US sanctions imposed against NSAs. These are justified at least as measures under national law to tackle a national emergency and

\footnotetext{
${ }^{53}$ UN Doc S/RES/1373 (2001) op para 2.

${ }^{54}$ See generally R. Liivoja, 'The Scope of the Supremacy Clause of the UN Charter' (2008) 57 ICLQ 583

${ }^{55}$ Al-Jedda v. United Kingdom, Application No.27021/08, Judgment 7 July 2011; Nada v. Switzerland, Application No. 10593/08, 12 September 2012

${ }^{56}$ But see Bernhardt, 'Article 103', in B. Simma (ed), The Charter of the United Nations: A Commentary ( $2^{\text {nd }}$ edn Oxford University Press 2002) 1300, where the author states, after noting the formula used whereby the UNSC 'calls upon' all states and other state-based actors to act in accordance with the provisions of the resolution notwithstanding the existence of rights and obligations under treaties, agreements, contracts or licences: 'It is interesting to note that the present standard formula does not expressly refer to Art. 103, but is obviously based on this Article (and Art. 25) of the Charter. At the same time the formula is broader than Art. 103 in several respects. It is not only addressed to States (to all States), but also to international and regional organizations, and it includes rights and obligations derived from contracts, licences and permits. In conclusion, it seems now to be generally recognized in practice that binding SC decisions taken under Chapter VII supersede all other commitments'.

${ }^{57}$ By the Helms-Burton Act 1996 (Cuban Liberty and Democratic Solidarity (Liberated) Act of 1996, 22 U.S.C $\S$ 6021-609). See A. Reinisch, 'A Few Public International Law Comments on the Cuban Liberty and Democratic Solidarity (LIBERTAD) Act of 1996’ (1996) 7 EJIL 545.

${ }^{58}$ See, for example, the Iran Sanctions Act of 1996, as Amended 50 U.S.C. $§ 1701$ note.

${ }^{59}$ A. Stephanson, Manifest Destiny: American Exceptionalism and the Empire of Right (Farrar, Straus and Giroux 1996).
} 
threat to the US represented by the activities of dangerous NSAs. Although there is evidence of such measures being extended to foreign companies and nationals who have breached sanctions imposed against NSAs, ${ }^{60}$ such extensions would seem necessary at least to make the measures effective and, in any case, are restricted in application to sanction-breakers found within US jurisdiction. ${ }^{61}$ Certainly in the case of collective sanctions, and given the mobility, as well as the foreign nationality, of most NSAs, it seems inevitable that sanctions directed at them and their behaviour can only be made to work effectively if the secondary measures necessary to alter the behaviour of companies and individuals towards those targeted should at least be applicable to foreign nationals and companies whichever jurisdiction they enter or are located within.

The problem with US sanctions against NSAs is that they are often imposed unilaterally, or go beyond those measures imposed by the UN Security Council, thereby subjecting foreign companies and individuals within US jurisdiction to penalties for their dealings elsewhere which have not been agreed at the international level. Nonetheless, these measures could be defensible legally if they can be seen either as the legitimate application of temporary countermeasures to enforce fundamental norms of the international community or, even more controversially, the unilateral enforcement of international public order norms. Both of these are controversial legal bases as the legality of countermeasures to enforce fundamental international laws was left open in the Articles on the Responsibility of States for Internationally Wrongful Acts of $2001,{ }^{62}$ although there is state practice to support such a right. ${ }^{63}$ The legality of enforcing international public order norms based on unilateral perceptions of peace and security would seem to be even more problematic not only in terms of the basic rules governing coercion in international relations but also for the stability of those relations. The characterisation of sanctions as domestic measures to respond to national emergencies, as stated in US executive orders, cannot normally shield them from the international legal order as the targets are often a combination of government figures and members of regime elites in another state - in other words they are part of inter-state relations and, therefore, governed by international law. Even international terrorist organisations, though not part of state structures, are located in other countries and therefore measures aimed at them, even largely taken within domestic legal orders, are subject to the norms of international law.

\section{Implementation and Accountability}

The typical method of implementation used by the UN Security Council for most of its sanctions regimes is the creation of a sanctions committee as a subsidiary organ, the task of which is to receive and review state reports on implementation. ${ }^{64}$ However, this has become more sophisticated over the years, and studies show how these methods of implementation and oversight have been adapted to sanctions against NSAs involving an increasing role for experts (in themselves another form of NSA) ${ }^{65}$ The Informal Working Group of the Security Council on sanctions has recommended measures to improve the effectiveness of sanctions. In 2006 it reported that:

\footnotetext{
${ }^{60}$ See, for example, Executive Order 13608 - Prohibiting Certain Transactions With and Suspending Entry Into the United States of Foreign Sanctions Evaders With Respect to Iran and Syria, 77 FR 26409, May 3, 2012. ${ }^{61}$ See, for example, Executive Order 13622-Authorizing Additional Sanctions With Respect to Iran, 77 FR 45897, July 30, 2012, which, inter alia, authorized the Secretary of the Treasury, in consultation with the Secretary of State, to prohibit the opening, and prohibit or impose strict conditions on the maintaining, in the United States of a correspondent account or a payable-through account by any foreign financial institution that has knowingly conducted or facilitated any significant financial transaction with the National Iranian Oil Company (NIOC) or Naftiran Intertrade Company (NICO).

${ }^{62}$ Article 54 Articles on Responsibility of States for Internationally Wrongful Acts 2001.

${ }^{63}$ E. Katselli-Proukaki, The Problem of Enforcement in International Law: Countermeasures, the Non-Injured State and the Idea of International Community (Routledge 2010) 102-209.

${ }^{64}$ On Sanctions Committees see Chapter 8 of this volume by Thilo Marauhn and Ignaz Stegmiller.

${ }^{65}$ J. Farrall, 'Should the United Nations Security Council Leave it to the Experts? The Governance and Accountability of UN Sanctions Monitoring' in J. Farrall and K. Rubenstein (eds), Sanctions, Accountability and Governance in a Globalised World (Cambridge University Press 2009) 191 at 209; criticises the UN
} 
For targeted sanctions to be effective, appropriate action must be taken at all decision-making levels: the Security Council, the sanctions committee, Member States and their administrative agencies. Proper design, implementation, ongoing evaluation and follow-up of sanctions regimes are key elements that contribute to the effectiveness of sanctions. ${ }^{66}$

Further:

The establishment of sanctions monitoring mechanisms is an important innovation in the structure of Security Council sanctions regimes, which has contributed to more effective sanctions implementation. Through their inquiries in States affected by sanctions, these mechanisms have shed significant light on how targeted sanctions, including arms embargoes, are implemented, as well as on various possible ways that sanctions are violated. These mechanisms have contributed to an understanding of both the nature and scope of obstacles to more systematic compliance, thereby enhancing the overall capacity of the United Nations to refine and tighten targeted sanctions measures. ${ }^{67}$

While effectiveness in targeting NSAs with the specific design of stopping them from acting in ways that threaten international peace and security is increasing we have to bear in mind the balance between effectiveness and legality. It is interesting to note how the Working Group connects the two:

Sanctions monitoring mechanisms are established by the Security Council in support of subsidiary organs. As such, they are organs with different and distinct mandates, of independent, expert and non-judiciary character, with no subpoena powers, whose primary role is to provide sanctions-related information to the relevant committees. However, given that the findings of the monitoring mechanisms (either their reports or documents or testimonies of their individual members), may be used by judicial authorities, their methodological standards may affect the credibility of the Organization. ${ }^{68}$

Given that targeted measures against NSAs can be seen as situated at the interface of the international legal and political orders, challenging such measures is clearly problematic. This leads to a discussion of possible review and other mechanisms of accountability that may be available to the targets of sanctions. Under those sanctions against NSAs operated by means of listing individuals or entities, the process of listing in the UN is a relatively straightforward one whereby a state can request such. The relevant Committee (the 1267 Sanctions Committee for instance) then makes decisions, normally by consensus, to add to the list of targeted individuals or entities ${ }^{69}$ Once an individual or entity is on a list the range of measures decided upon by the UN Security Council are imposed by member states carrying out their obligations under the UN Charter. The 'listing of individuals is conceived as an executive or administrative process on the basis of perceived security threats, rather than a judicial one' or penal one, 'even though the listing results in a set of coercive measures, arguably de facto punishment, of those listed'.$^{70}$ The process of delisting is seen in the UN as a political one, involving diplomatic protection and, more recently, access to an ombudsperson. Nonetheless, this has not prevented some targeted individuals from successfully bringing claims before judicial bodies: national, regional, and international, on the basis that their rights have been violated, the jurisprudence of which has been analysed elsewhere in this volume. ${ }^{71}$

\footnotetext{
Security Council's 'delegation of sanctions responsibilities to independent expert bodies' as amounting to 'outsourcing of its peace and security responsibilities'; and at 211 advocates the creation of permanent sanctions monitoring machinery within the UN Secretariat.

${ }^{66}$ Report of the Informal Working Group of the Security Council on General Issues of Sanctions (UN Doc S/2006/997) para 2.

${ }^{67}$ Ibid., para 17.

68 Ibid., para 19.

69 The 1267 Committee was established by op para 6 UN Doc S/RES/1267 (1999). On the listing process and its lack of transparency see D. Hovell, 'The Deliberative Deficit: Transparency, Access to Information and UN Sanctions', in J. Farrall and K. Rubenstein (eds), above note 62, 92 at 93-96.

${ }^{70}$ Tsagourias and White, above n.37 at 239.

${ }^{71}$ See Chapter 9 by Monica Lugato in this volume.
} 
In the case of targeted sanctions imposed against terrorist NSAs the temporary freezing of an individual's assets, and restricting their movements, can constitute preventive administrative measures necessary to prevent the threat from terrorism manifesting itself in indiscriminate acts of violence. As such they are not subject to due process, at least fair trial, protections. However, a number of listings appear to be almost permanent without real review, and like indefinite preventive detention, cease to be a response to an imminent existential threat but are rather forms of punishment without due process of law. There is a clear need to be able to challenge these decisions, if sanctions against NSAs are to maintain their legitimacy as a modern and sophisticated form of tackling threats. There is a danger that by allowing for quasi-permanent listings the $\mathrm{UN}$ is endorsing a system of punishment for wrongs determined by executive organs of states and organizations without any determination or trial before a court. Rather like targeted killings, the roles of judge, jury and executioner are rolled together. This is even more so as regards the auto-interpretation system of targeted measures triggered by UN Security Council Resolution 1373 (2001) adopted after 9/11 of 2001. This piece of UN Security Council lawmaking has legitimated the development of separate 'lists' of terrorists by member states, fulfilling their obligations under that resolution to: criminalise the financing of terrorism; freeze any funds related to persons involved in acts of terrorism; deny all form of financial support for terrorist groups; suppress the provision of safe haven, sustenance or support for terrorists. ${ }^{72}$ Given that there are no specific terrorist organisations listed in the Resolution, or by a collective process set up by the Resolution, 1373 gives states discretion to target those organisations and individuals it considers to be terrorists. In the UK, for example, the Terrorist Asset-Freezing Act 2010 gives effect to Resolution 1373 (2001) in the UK. The 2010 Act provides the UK government (HM Treasury) with powers to freeze the funds and economic resources of those suspected or believed to be involved in terrorist activities, and restricts the making available of funds, financial services and economic resources to, or for the benefit of, such persons.

Resolution 1373 potentially allows states to list NSAs for a wide range of reasons some of which are only very loosely connected to peace and security. The Counter-Terrorism Executive Directorate (CTED) was set up by the Security Council to provide the Counter-Terrorism Committee (CTC) established by Resolution 1373 with expert advice. In its Global Implementation Survey of 2009 CTED identified problems within a number of states in implementing the obligations in 1373 including: the lack of definition of terrorism in domestic law (or vague or overbroad definitions); arbitrary executions and detentions; torture and ill-treatment at the investigative stage; and the return of individuals to states in violation of the principle of non-refoulement. ${ }^{73}$

\section{Early Sanctions Regimes Against NSAs}

\subsection{UNITA in Angola}

As has been stated targeted sanctions against NSAs are basically a post-Cold War phenomenon. The early examples are an extension of state-focused sanctions as they were directed against entities in control of territory, exemplified by the measures imposed by the UN Security Council against the Angolan rebel group - UNITA, an armed group fighting an internecine war against other factions and then the government since the mid-1970s. By the early 1990s, with the Cold War props removed from the warring parties, signs of peace could be discerned.

In Resolution 864, adopted on 15 September 1993, the UN Security Council strongly condemned UNITA and held 'its leadership responsible for not having taken the necessary measures to comply with the demands made by the Council in its previous resolutions'; and expressed determination to "ensure respect for its resolutions and the full implementation of the "Acordos de Paz". The Security Council determined that 'as a result of UNITA's military actions', the situation in Angola constituted 'a threat to international peace and security', and then proceeded to act under Chapter VII of the

\footnotetext{
72 UN Doc S/RES/1373 (2001) op para 2.

${ }^{73}$ UN Doc S/2009/620.
} 
Charter of the United Nations. The decision was a clear response to a threat to the peace for which UNITA was deemed responsible. Responsibility was for the continuing threat caused by failure to comply with the peace agreement. This was made clear in the operative parts of the Resolution that decided that the measures listed in the Resolution would come into force ten days after its adoption "unless the Secretary-General notifies the Council that an effective cease-fire has been established and that agreement has been reached on the implementation of the "Acordos de Paz" and relevant resolutions of the Security Council' ${ }^{74}$ This was an express threat of sanctions unless UNITA fulfilled its obligations under the peace agreement. The primary aim was to change behaviour and thereby address the threat to the peace. The aim was to secure peace not to enforce compliance with international law, except if preventing and tackling threats can be understood as a form of enforcement of international public order norms of which compliance with an 'internal' peace agreement is a part. $^{75}$

The measures threatened by the Security Council, and then imposed when UNITA did not comply, initially required states to prevent the supply to UNITA of 'arms and related matériel of all types, including weapons and ammunition, military vehicles and equipment and spare parts for the aforementioned, as well as of petroleum and petroleum products ${ }^{76}$ The sanctions matched the violations in the sense that the continuing threat had been caused by UNITA's commitment to continue fighting, and the measures were aimed at cutting off its capacity to do so. Furthermore, the Security Council promised further measures including 'trade measures against UNITA and restrictions on the travel of UNITA personnel', unless the Secretary-General had reported by 1 November 1993 that an effective cease-fire had been established and that agreement had been reached 'on the full implementation of the "Acordos de Paz" and relevant resolutions of the Security Council'. ${ }^{77}$ The gradual ratcheting up of pressure against UNITA was manifested in subsequent resolutions of the Security Council as it continued to press UNITA into compliance with the peace agreement and, thereby, end the threat to the peace caused by UNITA. It was not until 1997 that travel restrictions were put in place on all senior UNITA officials and their families, combined with immediate closure of UNITA offices around the world and a denial of UNITA access to aircraft. ${ }^{78}$ This could be seen as introducing an element of punishment of UNITA members and denial of their rights - to freedom of movement rather than simply measures imposed to address the threat caused by UNITA, but such broadening of measures is inevitable if the targets refuse to comply. The realisation of the potential impact of these broader measures led to the invocation for the first time in this case of the humanitarian exception clause, found in most sanctions regimes. In 1997 the UNSC decided that the measures did not apply to 'cases of medical emergency or to flights of aircraft carrying food, medicine, or supplies for essential humanitarian needs, as approved in advance by the Committee created pursuant to resolution $864{ }^{\prime} .{ }^{79}$ Further measures were threatened in 1997 against UNITA unless it complied with its obligation to follow the peace process. ${ }^{80}$ Such measures included an assets freeze on UNITA and its senior officials, and an obligation to prevent the import of conflict diamonds from Angola, as well as a prohibition on the supply of mining equipment and vehicles. These were imposed by the Security Council in $1998,{ }^{81}$ thereby trying to prevent UNITA using funds from the export of diamonds or other minerals to finance its continuing rebellion. It was not until 2002, some nine years after the initial application of sanctions against UNITA, that the Security Council was able to welcome UNITA's commitment to the full implementation of the 'Accordos de Paz'. Both sanctions and the monitoring mechanism were terminated in that year. ${ }^{82}$

\footnotetext{
74 UN Doc S/RES/864 (1993) op para 17.

75 On the international legal status of peace agreements between a government and NSAs see S. Sheeran, 'International Law, Peace Agreements and Self-Determination: The Case of Sudan' (2011) 60 ICLQ 423 at 426 31.

${ }^{76}$ UN Doc S/RES/864 (1993) op para 19.

${ }^{77}$ Ibid., op para 26.

${ }^{78}$ UN Doc S/RES/1127 (1997) op para 4.

${ }^{79}$ Ibid., op para 5.

${ }^{80}$ Ibid., op para 10.

${ }^{81}$ UN Doc S/RES/1173 (1998) op paras 11 and 12.

${ }^{82}$ UN Doc S/RES/1448 (2002).
} 
The Security Council did not explicitly order states to place the obligations arising from these resolutions on Angola over any other conflicting treaty commitments they might have. Article 103 was invoked in non-obligatory terms by the Security Council calling upon 'all States, and all international organizations, to act strictly in accordance with the provisions of the present resolution, notwithstanding the existence of any rights or obligations conferred or imposed by any international agreement or any contract entered into or any licence or permit granted prior to the date of adoption of this resolution' ${ }^{83}$ Nonetheless, in order to fulfil their obligations under Charter arising from the resolutions, it is inevitable that states would have to give priority to those obligations when they conflicted with other existing international legal duties. In this vein the Security Council also called 'upon States to bring proceedings against persons and entities violating the measures imposed by this resolution and to impose appropriate penalties' ${ }^{84}$ Again the language was not one of obligation but it is difficult to see how states could ensure compliance with their obligations unless they criminalised or otherwise outlawed (by administrative or legislative measures) and punished such behaviour.

In terms of monitoring and implementation, the 1993 resolution established a Committee of the Security Council consisting of all the members of the Council to undertake tasks of reviewing state reports on measures taken to comply with their obligations arising under the UN Charter by reason of binding decisions of the Security Council and, by gathering information on violations, to report on its work to the Council with its observations and recommendations. ${ }^{85}$ The measures against UNITA were best characterised as non-forcible collective measures taken by the Security Council in order to tackle a threat to international peace and security caused by UNITA's on-going failure to comply with the peace accords by continuing to fight, and not as a punishment for UNITA's violations of the accords or rules of international law, particularly international humanitarian law.

\subsection{Bosnian Serbs}

The division between measures imposed to confront threats to the peace and sanctions as punishment for breaches of international law appears to break down when considering those measures imposed against the Bosnian Serbs in the 1990s, the party to the conflict seen as acting most often in violation of international humanitarian law. ${ }^{86}$ While certain measures were taken on the basis that the violations of international law themselves constituted threats to the peace, particularly the creation of the ICTY, ${ }^{87}$ other non-forcible measures were imposed upon the Bosnian Serb leadership for refusing to settle peacefully and to continue fighting, and so were imposed and designed to tackle the threat to the peace caused by the Bosnian Serbs continued aggression. Furthermore, the non-forcible measures taken by the UN Security Council to tackle violations of international law (viz the establishment of the ICTY) were not targeted at the Bosnian Serbs leadership per se but at individual violators of international criminal law (including individuals from other NSAs as well as emerging states). That aspect of the threat arising from the violence in Bosnia and consisting of violations of international law was addressed by the creation of an international criminal tribunal with powers of punishment,

\footnotetext{
${ }^{83}$ UN Doc S/RES/864 (1993) op para 20. See also UN Doc S/RES/1127 (1997) op para 10.

${ }^{84} \mathrm{UN}$ Doc S/RES/864 (1993) op para 21.

${ }^{85}$ UN Doc S/RES/864 (1993) op para 22.

${ }^{86}$ Final Report of the Commission of Experts Established Pursuant to Security Council Resolution 780 (1992), UN Doc S/1994/674.

${ }^{87}$ The ICTY was created by UN Doc S/RES/827 (1993), which expressed its grave alarm at the widespread violations of IHL; determined that 'this situation' constitutes a threat to international peace and security; determined to put an end to such crimes and to take effective measures to bring to justice those persons responsible for them; 'convinced that in the particular circumstances of the former Yugoslavia the establishment as an ad hoc measure by the Council; of an international tribunal for the prosecution of persons responsible for serious violations of international humanitarian law would enable this aim to be achieved and would contribute to the restoration of peace and maintenance of peace'. In other words tackling violations of international law was itself one measure taken to address a threat to the peace - see Judgment of the Appeals Chamber of the ICTY in the Tadic case Case No. IT-94-1-IT, 10 August 1995, para 19.
} 
while the continuing conflict and refusal to settle peacefully were addressed by a variety of nonforcible and forcible measures imposed by the Security Council.

Article 41 empowers the Security Council to use a range of non-forcible measures to tackle threats, one type being 'sanctions' or coercive targeted measures aimed at limiting the capabilities of NSAs and thereby stopping, or at least limiting, the fighting; another being an international criminal tribunal whose creation was aimed at deterring the commission of egregious violations of international criminal law, the commission of which violated human security and thereby contributed to the overall threat. The Security Council has increasingly recognised that the protection of civilians is an important function in its overall responsibility under Article 24 of the Charter to maintain and restore peace and security. ${ }^{88}$

In a decision adopted in 1994 (Resolution 942), the Security Council imposed measures after:

Expressing appreciation for the efforts undertaken by the representatives of the United Nations, the European Union, the United States of America and the Russian Federation to assist the parties in reaching a settlement,

Reaffirming the need for a lasting peace settlement to be signed by all the Bosnian parties, and implemented in good faith by them, and condemning the decision by the Bosnian Serb party to refuse to accept the proposed territorial settlement (S/1994/1081),

Viewing the measures imposed by the present resolution and by its previous relevant resolutions as a means towards the end of producing a negotiated settlement to the conflict. ${ }^{89}$

To drive home the link between recalcitrance in the peace process with its determination of a threat to the peace, the Security Council: first expressed 'its approval of the proposed territorial settlement for the Republic of Bosnia and Herzegovina which has been put to the Bosnian parties as part of an overall peace settlement'; secondly expressed 'its satisfaction that the proposed territorial settlement has now been accepted in full by all except the Bosnian Serb party'; and finally, strongly condemned the 'Bosnian Serb party for their refusal to accept the proposed territorial settlement, and demands that that party accept this settlement unconditionally and in full'.$^{90}$

The Resolution then obliged all states to undertake a range of measures to prevent 'economic activities' carried on within their territories by any entity, wherever incorporated or constituted, which was owned or controlled, directly or indirectly, by individuals or entities within areas of Bosnia controlled by the Bosnian Serbs. 'Economic activities' were defined broadly to include 'all activities of an economic nature, including commercial, financial and industrial activities and transactions, in particular all activities of an economic nature involving the use of or dealing in, with or in connection with property or interests in property ${ }^{9}{ }^{91}$ It was clear that the embargo did not apply to supplies for medical purposes and foodstuffs, or products for essential humanitarian needs, notified to the Sanctions Committee established by the Security Council in $1991 .^{92}$ In addition to a range of other non-forcible measures designed to cripple the economy of the Bosnian Serb areas, the 1994 resolution included an early version of the 'listing' process that has become emblematic of targeted sanctions in the modern era. The Security Council decided that states were to prevent the entry into their territories of members of the Bosnian Serb authorities, Bosnian Serb military and paramilitary authorities, those persons supporting Bosnian Serb forces, and those violating the measures imposed by this and a previous resolution and, further, requested that the relevant Sanctions Committee 'establish and maintain an updated list, based on information provided by States and competent

\footnotetext{
${ }^{88}$ UN Doc S/RES/1265 (1999).

${ }^{89}$ UN Doc S/RES/942 (1994). See also UN Doc S/RES/820 (1993). For US measures see Executive Order 12934, October 25, 1994 - Blocking Property and Additional Measures with Respect to the Bosnian SerbControlled Areas in the Republic of Bosnia and Herzegovina, stated to be not only adopted in the light of UNSC Resolution 942, but containing 'additional steps'.

${ }^{90}$ UN Doc S/RES/942 (1994) op paras 1-3.

${ }^{91}$ Ibid., paras 7-9.

92 UN Doc S/RES/724 (1991).
} 
regional organizations, of the persons falling within this paragraph ${ }^{93}$ These measures were only terminated in 1996 following the Dayton Accords and the holding of peaceful elections in Bosnia. ${ }^{94}$

\section{Al-Qaida: The Break With Territorially Focused Measures}

One trend in UN Security Council targeted sanctions against NSAs, noted above, is a move towards widening the concept of 'threat to the peace', so that action taken to tackle the threat include measures directed at deterring or stopping the violence by NSAs, and measures aimed at those responsible for violations of human rights law and humanitarian law. Although not present in the sanctions against UNITA, punitive non-forcible measures were included in the Security Council's responses to the violence in Bosnia but in the form of the creation of an international criminal tribunal. This approach was developed in relation to Libya in 2011, when targeted sanctions were combined with a referral to the ICC. However, in more recent episodes, sanctions (in the form of assets freezes, travel bans etc.) have been imposed on NSAs either because they undermine the peace process or otherwise threaten the peace, but also if they threaten the human security of civilians, manifested in the commission of violations of international law. This is a reflection of a move towards not only securing peace within the state but also in establishing the security of individuals within it. Thus, although appearing to be a form of punishment for breaches of the law, they remain measures aimed at restoring peace and security but at the level of civilians as well as the state. As well as the examples mentioned above, whereby sanctions were taken on this basis against NSAs in the DR Congo, and the CAR, other examples can be found in Cote D'Ivoire, ${ }^{95}$ Lebanon, ${ }^{96}$ and Sudan.${ }^{97}$ However, in other instances, targeted measures are more clearly of the UNITA-type, being directed at those regime elites and NSAs who have threatened the peace; for example in Guinea-Bissau, ${ }^{98}$ Iran, ${ }^{99}$ North Korea, ${ }^{100}$ Liberia, ${ }^{101}$ Sierra Leone, ${ }^{102}$ Somalia, ${ }^{103}$ Eritrea, ${ }^{104}$ South Sudan,,${ }^{105}$ and Yemen. ${ }^{106}$

The combination of state security and human security concerns is also found in UN Security Council targeted measures aimed at terrorist NSAs. Such measures have also shown an increasing global reach, by moving away from targeting NSAs found within specific states (although the measures themselves, such as the travel ban or assets freeze should be applied by all states), to targeting them wherever they are found, reflecting the global nature of certain terrorist networks. Initially, however, the anti-terrorist measures were more confined. Security Council sanctions against the Taliban and Al-Qaida originated in the late 1990s, with Security Council Resolution 1267 (1999) being adopted specifically in response to the harbouring of Al-Qaida by the Taliban regime in Afghanistan, and more generally as measures against international terrorism essential for the maintenance of international peace and security. Al-Qaida had already established its global terrorist credentials before September 2001 by its attacks on the US embassies in Tanzania and Kenya in 1998, mentioned in the preamble of Resolution 1267. The Resolution was directed at the Taliban for harbouring AlQaida and for refusing to extradite them. If the Taliban did not comply with the Security Council's demands to cease harbouring Al-Qaida, to take measures against them, and to hand Osama bin Laden

\footnotetext{
${ }^{93}$ UN Doc S/RES/942 (1994) op para 14.

${ }^{94}$ UN Doc S/RES/1074 (1996).

${ }^{95}$ For example UN Doc S/RES/1572 (2004) op para 9.

${ }^{96}$ For example UN Doc S/RES/1636 (2005) op para 3.

${ }^{97}$ For example UN Doc S/RES/1591 (2005) op para 3(c).

${ }^{98}$ UN Doc S/RES/2048 (2012) op para 6.

${ }^{99}$ For example UN Doc S/RES/1737 (2006) op paras 10, 12.

${ }^{100}$ For example UN Doc S/RES/1718 (2006) op para 8(c).

${ }^{101}$ For example UN Doc S/RES/1343 (2001) op paras 2, 5-7.

102 For example UN Doc S/RES/1132 (1997) op para 5.

${ }^{103}$ For example UN Doc S/RES/1844 (2008) op paras 1, 3.

${ }^{104}$ For example UN Doc S/RES/1907 (2009) para 14.

105 UN Doc S/RES/2206 (2015) op para 6.

${ }^{106}$ For example UN Doc S/RES/2140 (2014).
} 
over to countries where he had been indicted, the Security Council required all states to freeze funds owned and directly controlled by the Taliban, specifically to:

Freeze funds and other financial resources, including funds derived or generated from property owned or controlled directly or indirectly by the Taliban, or by any undertaking owned or controlled by the Taliban, as designated by the Committee established by paragraph 6 below, and ensure that neither they nor any other funds or financial resources so designated are made available, by their nationals or by any persons within their territory, to or for the benefit of the Taliban or any undertaking owned or controlled, directly or indirectly by the Taliban, except as may be authorized by the Committee on a case-by-case basis on the grounds of humanitarian need. ${ }^{107}$

The Security Council called upon 'all states to act strictly in accordance with the provision of this resolution, notwithstanding the existence of any rights or obligations conferred or imposed by any international agreement or any contract entered into or any licence or permit granted prior to the dates of coming into force of the measures'. Again the reference to the supremacy of UN obligations seems to be softened by the non-mandatory language whereby states are 'called upon' to act in accordance with those obligations notwithstanding any inconsistent obligations; nonetheless those obligations, including ones of prioritization, exist for states following a decision to impose measures under Chapter VII, by virtue of Articles 25 and 103 of the UN Charter. Its choice of language indicates that the Security Council recognises that the obligations to comply and to give priority to its decisions come from the Charter not from the organ directly. ${ }^{108}$ The measures would cease to apply as soon as the Taliban complied with its obligations under the resolution. ${ }^{109}$

UNSC Resolution 1333 (2000) extended these measures beyond members of the de facto government of Afghanistan to clear NSAs, namely Osama bin Laden and 'individuals and entities associated with him as designated by the Committee', including those in Al Qaida. As well as an assets freeze, and being denied access to finances and arms, members of Al Qaida and its supporters were, if listed, also subject to travel bans. The relevant paragraph required states:

To freeze without delay funds and other financial assets of Usama bin Laden and individuals and entities associated with him as designated by the Committee, including those in the Al-Qaida organization, and including funds derived or generated from property owned or controlled directly or indirectly by Usama bin Laden and individuals and entities associated with him, and to ensure that neither they nor any other funds or financial resources are made available, by their nationals or by any persons within their territory, directly or indirectly for the benefit of Usama bin Laden, his associates or any entities owned or controlled, directly or indirectly, by Usama bin Laden or individuals and entities associated with him including the Al-Qaida organization and requests the Committee to maintain an updated list, based on information provided by States and regional organizations, of the individuals and entities designated as being associated with Usama bin Laden, including those in the Al-Qaida organization. ${ }^{110}$

${ }^{107}$ UN Doc S/RES/1267 (1999) op para 4(b). Under op para 6 the 1267 Committee was established also to receive and consider information supplied by states on compliance and violations, and to designate individuals to be subject to the measures taken under op para 4.

${ }^{108}$ D.W. Bowett, 'Judicial and Political Functions of the Security Council and the International Court of Justice' in H. Fox (ed), The Changing Constitution of the United Nations (British Institute of International and Comparative Law 1997) 79-80.

${ }^{109}$ UN Doc S/RES/1267 (1999) op paras 4, 7, 14.

${ }^{110}$ UN Doc S/RES/1333 (2000) op para 8(c). On EU measures see Council Common Position 2002/402/CFSP concerning restrictive measures against Usama bin Laden, members of the Al-Qaida organisation and the Taliban and other individuals, groups, undertakings and entities associated with them and repealing Common Positions 96/746/CFSP, 1999/727/CFSP, 2001/154/CFSP and 2001/771/CFSP OJ L 139, 29.5.2002, p. 4. Amended by Common Position 2003/140/CFSP (OJ L 53, 28.2.2003, p. 62) (exceptions) and Council Decision 2011/487/CFSP (OJ L 199, 2.8.2011, p. 73) (amendment of title and scope). Most recently amended by Commission Implementing Regulation (EU) 2015/167 of 3 February 2015 amending for the 225th time Council Regulation (EC) No 881/2002 imposing certain specific restrictive measures directed against certain persons and entities associated with the Al Qaida network OJ L 28, 4.2.2015, p. 40-41 (to update the Al-Qaida terrorist blacklist to bring it in line with recent revisions by the United Nations Security Council Sanctions Committee). 
Resolutions 1989 and 1988 of 2011 finally separated the measures against the Taliban from those against Al-Qaida, thereby completely severing the nexus between Afghanistan and Al-Qaida, with the sanctions first imposed in Resolution 1267 being applied by the 1267 Committee to Al-Qaida, ${ }^{11}$ while Resolution 1988 created a new committee to administer those targeted measures directed at the Taliban. ${ }^{12}$ The targeted measures against the Taliban became more specifically directed at bringing them to the negotiating table. ${ }^{113}$

It is interesting to note that review by the ombudsperson established by UNSC Resolution 1904 in 2009 only applies to those on the Al-Qaida Sanctions List as administered by the 1267 Committee and not to any lists beyond that, including the Taliban list. This seemingly curious anomaly is probably explained by the overarching pragmatism of the Security Council on the matter of accountability for wrongly listing individuals; that complaints to international, regional and judicial bodies have derived largely from the 1267 list and the office of the ombudsperson is a response to that. ${ }^{114}$ The lack of remedies elsewhere in the UN system, for wrongly listed individuals, puts the creation of the ombudsperson in perspective, but it also fits the prevalent view in the Security Council that such measures are administrative ones taken in response to an international threat caused by the activities of international terrorist organisations and, therefore, any remedial measures should only be of a controlled administrative nature. However, as argued above, long-term listing constitutes a form of punishment that raises issues of legal remedies based on violations of due process norms found located in the international human rights obligations of states.

\section{Conclusion}

Sanctions against NSAs are now commonplace and they follow a distinct pattern in types of measures, whether imposed by the UN, EU or US. They are taken in response to threats to peace and security, although once one moves away from UN measures, the purposes and values protected may become broader and but are potentially not necessarily in the collective interest. Quite often international, regional and national measures are targeted at the same NSAs but there may be

Council Regulation 881/2002/EC imposing certain specific restrictive measures directed against certain persons and entities associated with Usama bin Laden, the Al-Qaida network and the Taliban, and repealing Council Regulation (EC) No 467/2001 prohibiting the export of certain goods and services to Afghanistan, strengthening the flight ban and extending the freeze of funds and other financial resources in respect of the Taliban of Afghanistan OJ L 139/9, 29.5.2002 p. 9. On US measures see, for example, Executive Order 13224—Blocking Property and Prohibiting Transactions with Persons who Commit, Threaten to Commit, or Support Terrorism, 66 FR 49079, September 24, 2001.

${ }^{111}$ UN Doc S/RES/1989 (2011); reaffirms the assets freeze, travel ban and arms embargo affecting all individuals and entities on the 1267 Committee's Al-Qaida Sanctions List. Decides to split the Consolidated List, after 'noting with concern the continued threat posed to international peace and security by Al-Qaida and other individuals, groups, undertakings and entities associated with it'.

112 UN Doc S/RES/1988 (2011); imposes an assets freeze, a travel ban and an arms embargo on individuals, groups, undertakings and entities associated with the Taliban in constituting a threat to the peace, stability and security of Afghanistan as designated by the Committee on the List established pursuant to resolution 1988 (2011).

${ }^{113}$ UN Doc S/RES/2160 (2014) op para 13 of which 'Underlines the importance of a comprehensive political process in Afghanistan to support peace and reconciliation among all Afghans, invites the Government of Afghanistan, in close coordination with the High Peace Council, to submit for the Committee's consideration the names of listed individuals for whom it confirms travel to such specified location or locations is necessary to participate in meetings in support of peace and reconciliation ...'.

${ }^{114}$ See criticism of the unevenness of access to remedies by Kimberly Prost in a briefing by the Ombudsperson at the Security Council's Open Debate on 'Working Methods of the Security Council' (S/2014/725): 'Enhancing Due Process in Sanctions Regimes', 23 October 2014, available at http://www.un.org/en/sc/ombudsperson/pdfs/SCBriefing23Oct2014.pdf (accessed 5 June 2015) 
differences in content and scope. Furthermore, consensus on taking such measures is harder to attain at the UN level than at the regional and, even more so, the national level, leading to autonomous regional and national measures, and raising questions about their compatibility with international laws governing non-forcible measures. The doctrine of counter-measures, which after all is confined tostate-to state responses but, moreover, is concerned with responses to violations of international laws not with threats to peace and security, is inadequate as a legal basis for many non-forcible measures taken at the sub-UN level. While there is room for collective measures taken to uphold international norms of public order at the regional level as well as the UN level, there are doubts about States unilaterally imposing such measures, even though they may be presented as responses to threats to that particular state. However, unlike some instances of unilateral sanctions imposed against States such as Cuba that do incur international censure, ${ }^{115}$ other unilateral sanctions taken against NSAs seem to be endured if not explicitly accepted as lawful.

Aspects of the sanctions regimes against NSAs are grounded in the existing state-based international legal order, by being a natural extension of sanctions regimes of the past imposed against states as a whole (for example Iraq and Serbia). Such sanctions regimes target those in power, regime elites, de facto authorities or rebels holding territory. The nexus to state-like authority and territory is clear. However, sanctions against NSA terrorist organizations or networks with genuine global reach are more challenging. Although they are clearly premised on protecting international public order norms and values, their scope and reach is potentially greater as the UN, regional organizations, and powerful states attempt to extend their application and effectiveness to tackle NSAs whose raison d'etre is to challenge the existing international legal order. International legal structures and processes are emerging to achieve these aims but it will be a number of years before the developments that started with sanctions against UNITA and the Bosnian Serbs not only address the threat represented by groups such as Al-Qaida, and the self-proclaimed Islamic State that operates across the Middle East, ${ }^{116}$ but also do so in a way that is coordinated and fully in accordance with international law. Indeed, there needs to be greater precision and clarity on the legal parameters and specific norms under which non-forcible measures, sanctions and countermeasures in the collective interest can be taken.

While it is easy to accuse powerful States of disregarding international norms, the fact is that there is a lack of progressive thinking on how to achieve a system of sanctions against NSAs that empowers but also limits sanctioning in ways that protects internationally agreed norms and values. A first step would be to clarify the nature and content of international public order norms aimed at promoting peace and achieving security (both the security of states and that of civilians - i.e. state security and human security) and, by so doing, place non-forcible measures more squarely in the international legal order than at present where their invocation is a matter of politics, although their effects are increasingly being judged in legal bodies at national, regional and international levels. What is clear is that to be both effective and lawful there needs to be a greater assimilation of international, regional and national responses to terrorists networks and other NSAs that represent threats not only to innocent individuals but to the existing international order.

\footnotetext{
${ }^{115}$ See for example UN Doc A/RES/67/4 (2012); EU, 'Demarches Protesting the Cuban Liberty and Democratic Solidarity Act' (1996) 35 ILM 397.

${ }^{116}$ In 2014 the UN Security Council started imposing targeted sanctions against Islamic State - see UN Docs S/RES/2170 (2014); S/RES/2178 (2014); S/RES/2199 (2015).
} 